\title{
Analysis of Ideological Practices in News Program Seputar Indonesia RCTI Through The 2014 Presidential Election Campaign
}

\author{
Dani Setiadarma ${ }^{1}$, Hendriyani² $^{2}$ \\ \{danisetiadarma77@gmail.com¹, hendriyani.sos@ui.ac.id²
}

Communication Department, Faculty of Social and Political Sciences, University of Indonesia, Indonesia ${ }^{1}$, Communication Department, Faculty of Social and Political Sciences, University of Indonesia, Indonesia ${ }^{2}$

\begin{abstract}
This research is intended to conduct a critical analysis of the news production process in the newsroom of the private television broadcasting company, Rajawali Citra Televisi Indonesia (RCTI). The research objective is to analyze the ideological discourse of news program Seputar Indonesia during the 2014 presidential election campaign. This type of research is qualitative. The research method is content analysis with Norman Fairclough's Critical Discourse Analysis approach.. Based on the results of descriptive analysis at the text level, interpretive analysis at the level of discourse practice, and explanative analysis at the level of sociocultural practice, this research shows that the ideology of the news program Seputar Indonesia, theoretically and based on the recognition of key informants as the owner's representation, can be ascertained that the discourse news ideology Seputar Indonesia in the 2014 presidential election campaign is the Social Responsibility press that does not represent the public interest. In practice, the news editorial follows the interests of capital owners who seem to side with one of the presidential-vice presidential candidates, namely Prabowo-Hatta. In addition, RCTI also does not seem to give freedom of space for journalists of Seputar Indonesia to have a different attitude from the policies of media owners if the topic of coverage involves the owner's political economy interests.
\end{abstract}

Keywords: Ideology practice, Mass media, Campaign news, and predidential election

\section{Introduction}

At present, mass media is an important element in democratic life as the fourth pillar of democracy that controls power and allows people to express opinions in following the course of government. Indicators of democratic media and communication life are guaranteed freedom of expression, freedom of speech and freedom of the press. At a time when state intervention and control over the media had decreased considerably, in this reform era, repression to news editors was still happening. An international organization engaged in journalist advocacy, Reporters Without Borders (RSF), noted that one form of repression in the World Press Freedom Index in 2018 was the pressure from media owners on news editors. Out of 180 countries, Indonesia's press freedom rank is $124^{\text {th }}[1]$.

Press freedom in Indonesia found its momentum through the 1998 reforms, after being restrained for 32 years during the Soeharto era. Law No. 32 of 2002 concerning broadcasting and Law no. 40 of 1999 concerning the press also opens up new opportunities in the broadcast media business with the hope that it will further increase the practice of independent journalism. A 
number of businessmen have emerged as new players in the television broadcasting business, previously only controlled by the Soeharto family and their cronies. However, the opening of the tap for freedom in media management has created a new problem, namely the media conglomeration. The rapid development of the private television business is only focused on 12 business groups, namely MNC Group, Kompas Gramedia Group, Jawa Pos Group, Mahaka Media Group, Elang Mahkota Teknologi, CT Corp, Visi Asia Group, Media Group, MRA Media, Femina Group, Tempo Inti Media, and Berita Satu Media Holding. In terms of ownership of television broadcasting media, MNC Group owns RCTI, Global TV and MNC TV; Emtek Group controls SCTV, Indosiar and Omni Channel TV; Visi Media Asia controls ANTV and TV One; CT Corp owns TransTV and Trans7 [2].

A number of media owners who control several media at once are members of political parties in Indonesia, such as Hary Tanoesudibjo (MNC) in the Perindo Party, Surya Paloh (Media Group) in the Democratic National Party, and Aburizal Bakrie in the Golkar Party. The control of the television broadcasting media by a handful of businessmen is detrimental to the media audience because it has the potential to create a monopoly on information and intervention in the newsroom. Instead of creating a democratization of information, media conglomerates actually eliminate press freedom. Media workers, in this case journalists, are vulnerable to being influenced by media owners in the news production process and in making decisions to determine which news is appropriate and which is not suitable for publication in news programs [3].

The news of the presidential election campaign is important in implementing a direct democracy system that involves broad public participation in every presidential and vice presidential election in Indonesia. In a democratic system, before the presidential election takes place, there is a campaign process for candidates as one of the important stages in the election to strengthen the support of the voting candidates. During the presidential election campaign period from 4 June to 5 July 2014, the two candidate pairs who competed were the presidential and vice presidential candidates Joko Widodo-Jusuf Kalla (Jokowi-JK) and Prabowo-Hatta Rajasa. The balance of information and fairness of representation is a prerequisite for the realization of the idea of mass media as a public space. But in reality, the 2014 presidential election campaign coverage on the news program Seputar Indonesia RCTI did not appear to be independent due to the conflict of interest involving the media working class, namely journalists in the newsroom or news room with media owners who were also politicians. The newsroom is not a sterile blackbox, but there is an editorial policy that must be obeyed. In fact, the owners of capital have the right to enforce and enforce the policies of the media company. Due to pressure from the media owners, the news writing process encountered many conflicts of interest [4].

Media managers always carry out a selection process in presenting message content in carrying out its functions. Materials that are used as news programs and entertainment programs, as well as the socialization offered by the media, have been filtered beforehand. In the evening newscast NBC Nightly News and articles New York Times during the election period in 1996, 2000, 2004 and 2008 the volume coverage of the campaign and the percentage of coverage is not balanced against the candidates in future elections. Mass media is a filter that filters various things to be given attention or not. The selected issue or information is then packaged in such a way as to form a certain construction or appearance. Thus, the audience is not only chosen about something that according to the media deserves attention, but is also directed to see it from a certain point of view [5]. The news of Seputar Indonesia RCTI in the 2014 Indonesia presidential election campaign is the result of the construction of this media. In the United States, uneven in coverage that have effect to the voters who watch or read the news also happened. Evening newscast NBC Nightly News and articles New York Times during the election period in 1996, 2000, 2004 and 2008 was not balanced in the volume coverage of the campaign and the percentage of coverage is against the candidates in future elections [6]. There was also media bias in MSNBC, FOX and $\mathrm{CNN}$, due to interference from their owners [7]. 
The ideology of news coverage in the mass media which is wrapped in the agenda of the presidential election campaign is part of social change that is increasingly fast and increasingly widespread. News management in RCTI's news room which produced the news program Seputar Indonesia has a tendency not to adhere to the principle of independence as an ideology that must be upheld because the interests of media owners strongly influence text construction in the newsmaking process. Those who control the media usually also have ownership in the business sector and have certain political interests [8]. In the case at RCTI, the news division is prohibited from producing content that is detrimental to the interests of the company or media owners. RCTI is part of the MNC Group, where the largest share is owned by Hary Tanoesudibyo, an activist of the Red and White Coalition (KMP) who supports Prabowo-Hatta. In the news, Seputar Indonesia tends to highlight and emphasize Prabowo-Hatta compared to Jokowi-JK. RCTI journalists who try to be critical of the news production process and uphold the journalistic code of ethics must even prepare to face conflicts with media owners. It is stated that news written by journalists should side with the public interest, not to companies and advertisers [9]. But in fact, critical journalists do not have a major place in the company.

Based on the description of the problem above, this research focuses on the discourse of media ideology in mass media coverage related to the 2014 presidential election campaign, by taking research on RCTI's news program Seputar Indonesia. Thus, the title of this research can be formulated, "The Analysis of Ideological Practices in Television Program of Seputar Indonesia RCTI through the News of the 2014 Presidential Election Campaign".

\section{Methods}

The paradigm used in this research is based on the critical paradigm. This paradigm aims to reveal the false awareness behind things that are considered objective. The goal, among others, is to obtain findings that have social significance, such as social criticism, awareness, empowerment, or social transformation. Research with a critical paradigm must be associated with efforts to address the problem of injustice felt by a particular society [23].

The type of research is part of qualitative research using the Content Analysis Method. Meanwhile, the analytical approach is Norman Fairclough's version of Critical Discourse Analysis. Therefore, this research is in the realm of a critical paradigm. In this stage, inductive thinking is used and finally it becomes a theory through the process of forming new concepts (conceptual formation) and theory formation (grounded theorizing) [24].

The subject of research is news Seputar Indonesia on RCTI regarding the 2014 presidential election campaign which it consisted of 8 (eight) news broadcast during the campaign period, the media journalist, commissioners and members of the research and development team of the Indonesian Broadcasting Commission (KPI, Komisi Penyiaran Indonesia), as well as audience representations of television viewers. The object of research is the ideology and political economy of the 2014 presidential election campaign news broadcasted during the campaign period. Furthermore, the data collection techniques that will be used in this research are:

a. Text Analysis, which is the collection of data on the structured dimension of the text by utilizing linguistic analysis of vocabulary, sentences, propositions, and paragraphs to explain a text. At this level, the news text Seputar Indonesia is analyzed linguistically by looking at vocabulary, semantics, and sentence structure. He also includes coherence and cohesiveness, how the combination of words or sentences can form the meaning of these elements aiming to see 3 problems, namely ideational, relation and identity. Ideational, which refers to a particular representation that you want to appear in the text, which generally carries a certain ideological content. Relations, which refers to the construction of the relationship between journalists and viewers. Identity, which refers to a certain construction of the identity of the journalist and 
audience and how this person and identity is to be presented (micro-level analysis). The analysis was carried out on the news of Seputar Indonesia that had been collected and broadcast during the 2014 presidential election campaign period. This video recording was obtained from the Indonesian Broadcasting Commission which will be used for textual analysis.

b. Indepth Interviews, this in-depth interview technique is a technique of collecting data by conducting in-depth interviews with related parties as key sources in order to complete primary data at the level of discourse practice, namely 3 journalists from Seputar Indonesia. Analysis at the level of discourse practice focuses on the production of the text Seputar Indonesia. Text is formed through a discourse practice that will determine how the text is produced. The production of the text Seputar Indonesia observes three things. The first is the identity of the discourse maker. If the discourse is in the form of news, then the discourse maker is the journalist who makes the news. The second thing is the relationship between the discourse maker and the media organization structure in which the discourse was formed. The third thing is the routine or work practice of the discourse production. These three things are an interrelated whole of discourse practice in a media.

In addition, at the sociocultural practice level or macro level, the author also conducted interviews with 4 resource persons who work as academics in the field of communication science, national political observers, commissioners and members of the research and development team of the Indonesian Broadcasting Commission as representatives of the public. readers to analyze media discourse on its social context.

c. Literature and documentation study, which is a data collection technique carried out by collecting written materials, reading books, documents regarding government policies in the media industry, media organization policies, advertising data, in order to obtain various theories and concepts, which have relevance to the objectives of this study. This technique is to complement primary and secondary data at the level of sociocultural practice (level three analysis).

d. Observation, which is a data collection technique that is carried out by direct observation and recording of the research subject in order to obtain primary and secondary data on both news programs. In addition to in-depth interviews, researchers also made observations, and the results of observations were recorded using field notes. Observations were made in a participant manner, this is related to the work experienced by researchers as producers of Seputar Indonesia during the 2014 presidential election campaign. In the process of compiling news, researchers have the opportunity to meet and chat with all journalists on duty, from reporters, producers, executives. producer and editor in chief.

\section{Results and Discussions}

In a discussion about the ideological discourse of the news program Seputar Indonesia RCTI in the coverage of the 2014 Presidential Election Campaign for the Republic of Indonesia during the period from 4 June to 5 July 2014, researchers obtained 8 news related to ideological discourse. Furthermore, in this sub-section of the discussion, the researcher will divide the eight stories into three major themes.

First, the theme of text construction that shows Prabowo's superiority over Jokowi, both personally and as a presidential-vice presidential candidate. This can be seen in the construction of the text in the news program Seputar Indonesia entitled "Prabowo Bicara" edition of June 4, 2014, where Prabowo was specially interviewed at his residence which has a number of farms. Prabowo for about four minutes talked about the potential of livestock and agriculture in Indonesia while conveying his vision in the economic sector regarding Indonesia which must return to being an 
Asian tiger. On July 5 2014, the headline was "Indonesia's Chosen President”. Seputar Indonesia, directing public opinion that Prabowo is superior to Jokowi and has the support of President Soesilo Bambang Yudhoyono along with seven other parties supporting the Red and White Coalition. As usual in every contestation, all participants compete to become champions / winners. Still in the 5 July 2014 edition, Seputar Indonesia with the title "Partai Demokrat Support Prabowo" is an affirmation of the construction of texts with the theme of Prabowo's superiority. This affirmation can be seen in the text: "Prabowo's vision and mission is in line with the Democratic Party in its economic and people's welfare programs".

In the 5 July 2014 edition, in the news entitled "Support Prabowo Hatta", Seputar Indonesia, further strengthening the text construction in the previous news which shows Prabowo's superiority over Jokowi by displaying the support of Indonesian Student Network students from 20 universities in Indonesia for Prabowo Hatta's partner. The construction of news on Seputar Indonesia further emphasizes the meaning that the importance of reporting is directed at affirming the superiority of Prabowo's figure as worthy of being the leader of Indonesia through the 2014 presidential election. This means that this meaning shows a very strong alignment for Seputar Indonesia towards Prabowo's presidential candidate.

Second, is the theme of text construction on public preference for Prabowo based on research results from survey institutions and on social media. The practice of discourse with the aim of constructing reality is carried out by referring to Hamad's opinion, that in constructing reality, the media makes use of three components: (1) Use of political symbols (language of politics), (2) framing strategies, and (3) Willingness of the media to give space (agenda setting function). These three are what determine the opinion that is formed (Hamad, 1999). The 4th edition of June 2014, Seputar Indonesia featured a story entitled "Indonesia's Chosen President". In the news, Seputar Indonesia featured Prabowo's speech as a presidential candidate as well as the results of a survey by the Indonesia Research Center which predicted Probowo would outperform Joko Widodo. The support of various political parties and figures and mass organizations was shown to be Prabowo's advantage. Meanwhile, it was reported that Joko Widodo was supported by market traders, without being accompanied by a campaign speech or an interview with Joko Widodo. Through this news, Seputar Indonesia is constructing a discourse that has marginalized Jokowi. The marginalization was carried out with an emphasis on how Jokowi is positioned in the news text, where the IRC survey results stated that Prabowo was superior to Jokowi. Such a position, according to Rachmadi (1990), is not only a journalistic technique, but also related to the politics of news (Rachmadi, 1990: 6).

In the news entitled "Alleged Leaks of Presidential Candidate Debate Material", Seputar Indonesia was broadcasting that there is an allegation of leaking of Presidential Candidate Debate material which benefits the presidential-vice presidential candidate pair Joko Widodo and Jusuf Kalla. Even though this news was deemed to have no clear news source by the Press Council and lacking strong documents to support its accusations, the framing strategies with the theme of leaking debate material for the presidential candidates further marginalized Jokowi, and was broadcast repeatedly in Seputar Indonesia Sore news program on 11 June 2014, Seputar Indonesia Malam on 11 June 2014 and Seputar Indonesia Pagi on 12 June 2014.

In the news of 11 June 2014 edition, the news presenter Seputar Indonesia discussed the theme of the Koran Sindo newspaper headlines entitled "Prabowo Most Liked". Seputar Indonesia, implementing a framing strategy by presenting Prabowo as the fifth political figure in the world with the most likes by Facebook social media users. News presenter Michael Tjandra discusses Prabowo who is at the top of the newspaper page, alongside other popular international figures such as Barack Obama (US President), Narendra Modi (Indian Prime Minister), Mitt Romney (politician and former US presidential candidate), and Arvind Kejriwal (politician and former candidate for prime minister of India). Facebook has become a medium for Indonesia in constructing messages with the aim of influencing public opinion. The central point in this construction is the opinion that is manifested in the language as discussed in the news with the 
theme of the level of public preference for the figure of Prabowo Subianto and as a candidate pair for the President-Cawapres Prabowo-Hatta.

Third, the text construction in which Wiranto's statement regarding Prabowo which related with the activist kidnapping case and the May 1998 riots actually became an advantage for Prabowo because he was considered the injured party. "Clarification of Prabowo", was the headline of the news program Seputar Indonesia on June 20, 2014. In the news, Seputar Indonesia constructed the news where Wiranto carried out a black campaign to 'attack' Prabowo with the activist kidnapping case, even though Prabowo had the documents dismissed with respect. Wiranto's statement regarding Prabowo who had violated the soldier's oath generated reactions against Wiranto but on the other hand it became an advantage for Prabowo, who was shown to be the loser. Prabowo's team stated that they would report Wiranto's statement as a 'black campaign' to Bawaslu. The practice of this discourse is considered counterproductive for Jokowi's camp and benefits Prabowo's camp.

The practice of media discourse cannot be separated from the interests of the owners of capital / media owners. Discourse is a reality that has been processed through being constructed by journalists into the form of news or opinions in the mass media. Therefore, apart from analyzing the text, the researcher also interviewed several internal sources on Seputar Indonesia, to confirm the results of the study regarding the practice of discourse (text consumption) Seputar Indonesia.

Regarding the practice of discourse and partiality Seputar Indonesia in the 2014 presidential election, the speakers shared their views. RCTI journalist Raymond Rondonuwu admitted that Seputar Indonesia seemed to side with Prabowo, and this attitude was carried out in violation of the Journalistic Code of Ethics. Seputar Indonesia was supporting Prabowo and criticizing Joko Widodo without paying attention to the Journalistic Code of Ethics. The Press Council decided that RCTI violated Article 1 and Article 3 of the Journalistic Code of Ethics regarding the clarity of the source of information related to the news "Alleged Leaking of Presidential Candidate Debate Material" which was held in the Seputar Indonesia program.

Regarding partiality Seputar Indonesia, the same thing was conveyed by Septiantoro. He did not deny that RCTI sided with Prabowo's camp, so that the news made did not prioritize a professional attitude and was less balanced, especially in the presentation of news on the 2014 presidential election campaign. The issue of professionalism and independence was strengthened by Septiantoro's statement which acknowledged the demand for various news angles that must focus the focus. on Jokowi's failure, for example regarding the Esemka car project which was considered a failure and vocational students who were disappointed because they were promised that after graduating they would get a job as the mayor of Solo. Another news angle is about the failure to organize the city of Solo. The Citywalk project became neglected when Jokowi became Governor of DKI Jakarta, resulting in a number of areas that had been converted to infrastructure development neglected.

Media observer Dhandy Dwi Laksono sees that media relations and political relations in the presidential election cannot avoid support. This process will take place automatically due to conflicts of interest of investors who already have certain political affiliations with certain candidates who are promoted by certain parties. It is hoped that professional journalists working in the media will have a bargaining position with media owners in the news production process. The mandate of the Press Law and the Broadcasting Law stipulates that the press must be independent and must not take sides. What RCTI has done clearly violates the Law, violates the Journalistic Code of Ethics and violates the rules of the KPI Broadcast Code of Conduct and Broadcast Program Standards (Pedoman Perilaku Penyiaran dan Standar Program Siaran, P3SPS). But the biggest violation committed was manipulating public rights by blocking and deceiving the public into objective facts. This mandate is defeated by the dominance of the interests of the owners of capital and their businesses. The same sitution happened in Malaysia in the election general in 2014, where the case is biased newspaper for the interests of politic of the media owners. Nearly all the mainstream media in Malaysia bias towards the ruling coalition, Barisan Nasional. Bias 
against political parties in the ruling coalition is associated with ownership of mainstream newspapers by political interests aligned with the current Malaysian government [25].

In a study of Seputar Indonesia regarding the domination of capital owners, Raymond Rondonuwu as a senior journalist at Seputar Indonesia, individually, does not have the freedom to write news. Raymond asked the editor-in-chief not to produce news about Prabowo's rivalry against Jokowi by using the Twitter source @ triomacan for fear of not being objective. Raymond Rondonuwu gives advice to make balanced news and not attack without a clear source of news. Raymond Rondonuwu's consideration to remain independent and not attack either party is a reason for idealism, showing that the power relationship between the owners of capital, on the one hand, and the workers on the other gives birth to the hegemony of the owners of capital. In fact, the organizational structure of Seputar Indonesia, especially at the technical level of the editorial team between the Editor in Chief and the News Producer where the ideology of the owners of capital is 'disguised' is conveyed, in Raymond's case it does not allow individuals to choose.

Regarding the practice of discourse carried out politely by Seputar Indonesia, the research informant, Dendhy Laksono reminded the mass media to be able to carry out the supervisory function of interpreting or giving meaning to political social situations that educate the community, become a propaganda tool in forming healthy opinions so as to create conducive conditions and society. brightest.

Based on the explanation above, from the normative perspective of the press, the researcher argues that the ideological discourse on Seputar Indonesia is the practice of the value of the Social Responsibility press which does not represent the public interest (Public Interest) and the perspective of a professional press. In the Social Responsibility press system, the right to freedom of broadcasting is accompanied by obligations towards the wider community that go beyond personal interests. The positive notion of freedom described involves several social goals. Responsible media will maintain high standards by self-regulation, but government intervention is also involved. Accountability mechanisms for the community and the public also exist. In this case, the public is seen more as a "customer" and journalism cannot be separated from marketdriven journalism because it tends to seek profit.

\section{Conclusions}

Based on the results of the descriptive analysis, there are several things that can be concluded as follows:

1) Seputar Indonesia claiming to uphold the values of Pancasila by providing space for opposing parties in it. But on the other hand, in the practice of reporting management in the news editorial, Seputar Indonesia prioritizes the interests of the owners of capital. Seputar Indonesia even attacking with negative issues, not prioritizing professional attitudes and maintaining independence with balanced coverage in the broadcasting of news on the 2014 presidential election campaign.

2) Seputar Indonesia, it seems that it does not provide space for individual journalists to have a slightly different attitude than owner policy. This attitude is actually driven by the orientation of the economic and political of the media owners.

Based on the two conclusions above, the researcher provides several suggestions as a solution to the current conditions in the news program of Seputar Indonesia, as follows:

1) Seputar Indonesia, it is necessary to reorganize the news editorial and management in the news production process, by holding back consistently to the essence of the press is in accordance with the National Press Law, Broadcasting Law, P3SPS KPI and the Journalistic Code of Ethics as subordinate to the sources of all national legal sources, namely Pancasila 
and the 1945 Constitution. RCTI must carry out media business management in a professional and proportional manner, not through capitalistic business management. As a private broadcasting institution that uses public frequencies, it must strengthen its role in providing literacy education to the public.

2) To implement the ideals of reform in national democratization, Seputar Indonesia should not manipulate public rights by blocking the public from objective facts in the news production process. Journalists should not be defeated by the dominance of the economic and political interests of media owners. Media owners should prioritize public interests as a form of service to the nation.

\section{References}

[1] I. P. I. P. F. Index, "World Press Freedom Index." 2018.

[2] Y. Nugroho, D. A. Putri, and S. Laksmi, "Mapping the landscape of the media industry in contemporary Indonesia. Report Series. Engaging Media, Empowering Society: Assessing media policy and governance in Indonesia through the lens of citizens' rights," Res. Collab. Cent. Innov. Policy Gov. HIVOS Reg. Off. Southeast Asia, funded by Ford Found. Jakarta CIPG HIVOS, 2012.

[3] I. Haryanto, "Media ownership and its implications for journalists and journalism in Indonesia," Polit. media twenty-first century Indones. Decad. Democr., pp. 104-118, 2011.

[4] W. Breed, "Social control in the newsroom: A functional analysis," Soc. forces, pp. 326-335, 1955.

[5] D. McQuail, "Mass Communication Theory: an Introduction: Teori Komunikasi Massa, Terj. Edisi Ke-1.” Erlangga: Jakarta, 1987.

[6] J. J. Weikert, Balancing act: How an unbalanced media affects the electorate. Temple University, 2013.

[7] H. Devaney, "Perceptions of media bias: viewing the news through ideological cues," A Sr. Honor Thesis, Univ. California, San Diego, 2013.

[8] E. S. Herman and N. Chomsky, Manufacturing consent: The political economy of the mass media. Random House, 2010.

[9] B. Kovach and T. Rosenstiel, The elements of journalism: What newspeople should know and the public should expect. Three Rivers Press (CA), 2014.

[10] G. Murdock and P. Golding, "For a political economy of mass communications," Social. Regist., vol. 10, 1973.

[11] V. Mosco, The political economy of communication: Rethinking and renewal, vol. 13. Sage, 1996.

[12] A. Giddens, The constitution of society: Outline of the theory of structuration. Univ of California Press, 1984.

[13] J. H. McManus, Market-driven journalism: Let the citizen beware? Sage Publications, 1994.

[14] A. Sobur, “Analisis Teks Media, PT,” Remaja Rosdakarya, Bandung, 2002.

[15] A. Armando, Televisi Jakarta di atas Indonesia: kisah kegagalan sistem televisi berjaringan di Indonesia. Bentang Pustaka, 2011.

[16] E. E. Dennis and J. C. Merrill, Media debates: Issues in mass communication. Addison-Wesley Longman Ltd, 1991.

[17] P. J. Shoemaker and S. D. Reese, Mediating the Message: Theories of Influences on Mass Media Content. 1996.

[18] J. Nerone and J. Nerone, "Four Theories of the Press," Oxford Res. Encycl. Commun., no. September, pp. 1-22, 2018.

[19] P. L. Berger and T. Luckmann, The social construction of reality: A treatise in the sociology of knowledge, no. 10. Penguin Uk, 1991.

[20] S. Hall, Representation: Cultural representations and signifying practices, vol. 2. Sage, 1997.

[21] A. Briggs and P. Cobley, The media: an introduction. Pearson Education, 2002.

[22] S. Hall, "Encoding/decoding," Media Stud. A Read., vol. 3, pp. 28-38, 2000.

[23] W. Lawrence Neuman, Social research methods: qualitative and quantitative approaches. Pearson, 2014.

[24] I. Hamad, "Konstruksi Realitas Politik Dalam Media Massa (Studi Pesan Politik Dalam Media Cetak 
Pada Masa Pemilu 1999)," Hubs-Asia, vol. 10, no. 1, 2010.

[25] M. A. M. Sani, "Malaysia's 13th general election: Political partisanship in the mainstream print media," Asia Pacific Media Educ., vol. 24, no. 1, pp. 61-75, 2014. 